\title{
MICROPALEONTOLOGICAL STUDIES ON THE THEBES FORMATION OF THE RED SEA COAST AND THE NILE VALLEY, EGYPT
}

AREF, Mahmoud M., Dept. of Geology, Kena University, Kena; KENAWY*, Abbas I., Dept. of Geology, Assiut University, Assiut, Egypt

Thirty-eight species of larger foraminifera belonging to Nummulites, Operculina and Assilina are recorded, identified and systematically described from 5 stratigraphic sections of the Thebes Formation in the Red Sea Coast and the Nile Valley, Egypt.

According to these species the age assigned to the Thebes Formation is Lower Eocene (Ypresian).

The Nummulites species are subdivided here into 6 groups based on their evolutionary lineage following Schaub (1981). Moreover, spiral diagrams for the different species showing the relation between the number of whorls and the corresponding radius in median sections are drawn. 